\title{
STUDIES ON YEAST FLOCCULATION. COMPARISON OF ENZYMATIC DIGESTS OF FLOCCULENT AND NON-FLOCCULENT CELLS OF SACCHAROMYCES CARLSBERGENSIS
}

by

PETER MARFEYa)

STEEN BECH SØRENSEN

and

\section{MARTIN OTTESEN}

\author{
Department of Chemistry, Carlsberg Laboratory \\ Gl. Carlsberg Vej 10, DK - 2500 Copenhagen, Valby
}

a) Permanent address: Department of Biological Sciences, State University of New York at Albany, Albany, New York 12222, U.S.A.

Keywords: Yeast flocculation, cell wall, trypsin, proteolysis

Treatment of a flocculent (strain 201) and a non-flocculent (strain 116) cell suspension of Saccharomyces carlsbergensis with trypsin, followed by $\beta$-mercaptoethanol and a second trypsin treatment solubilized approximately $15 \%$ of material from both types of cells based on dry weight. The solubilized fractions were resolved by Sephadex gel filtration into high mol.wt. $(40,000$ to 200,000$)$ and low mol.wt. (less than 4,000) components. High mol.wt. components from the flocculent cells contained more carbohydrate and less protein than the corresponding components isolated from the non-flocculent cells. Furthermore, the polypeptide material from the flocculent cells had a higher content of proline, lysine, and arginine than that from non-flocculent cells. High mol.wt. material contained antigenic determinants similar to those previously found in beer fractions. Yeast-derived antigens were found in all fractions while antigens of barley origin were found only in the tryptic digests.

A differential radioactive labelling technique demonstrated minor differences between the components released from flocculent and non-flocculent cell residues upon digestion with pronase.

\section{INTRODUCTION}

Yeast flocculation is the ability of some yeast strains to clump and form large aggregates resulting in the formation of either a head (top yeasts) or of a sludge (bottom yeasts). Floccula- tion is an inheritable characteristic involving interplay of nuclear genes and possibly cytoplasmic elements (17). The heritable character is expressed in the cell wall structure where variations in the phosphomannan- 
protein complex (4) may determine the degree of flocculence. The nature and density of ionic charges on the surface of cell envelope and the interference with this charge by adsorbed material from the medium may play a role in the expression of flocculence $(13,17)$. Yeast flocculation is influenced by the environment and is dependent on $\mathrm{pH}$, temperature and solvent composition (16). Some of the metal ions, notably $\mathrm{Ca}^{2+}$ ions $(21,22)$, and certain organic substances enhance flocculence while certain anionic substances and sugars are inhibitory (7). Flocculation is also exhibited by the isolated cell walls prepared from the flocculent yeasts (8). This indicates that the phenomenon is restricted to the surface of cell envelopes and does not involve cytoplasmic materials. The phosphomannan-protein complex appears to be responsible for this behaviour of the isolated cell wall because its removal by alkali (12), digestion with trypsin $(14,15)$ or digestion with papain (8) decreases flocculation.

The aim of our research was to isolate and partially characterize those components in the flocculent (strain 201) cells of Saccharomyces carlsbergensis which are responsible for flocculation and to compare them with the corresponding components derived from the non-flocculent (strain 116) cells. Instead of working with the isolated cell walls we subjected carefully washed intact cells to a series of treatments involving trypsin and $\beta$ mercaptoethanol. After radioactive labelling the residual cells were further digested with pronase. The material obtained in this manner was fractionated on Sephadex and Bio-Gel columns and characterized with respect to molecular weight, carbohydrate content, amino acid composition, and immunochemical properties.

\section{MATERIALS}

Saccharomyces carlsbergensis strain 116 (non-flocculent) and strain 201 (highly flocculent) were harvested at an early stationary phase and were maintained in a beer medium. Samples of strain 116 cells from logarithmic and from stationary phase were compared as to their metabolic activity using a standard assay system (API $20 \mathrm{C}$ kit) designed to test changes of $\mathrm{pH}$ during metabolism of various substrates. In general, both types of cells displayed similar metabolic activity towards a variety of substances. However, strain 116 cells from the stationary phase appeared to metabolize $\mathrm{D}(+)$ melibiose earlier ( 6 hours) than the cells from the logarithmic phase (24 hours). When the strain 201 cells were compared in the same manner it was found that the cells in the logarithmic phase metabolized maltose and $D(+)$-melibiose 3-6 hours earlier than the cells from the stationary phase. Otherwise, there was no difference in metabolism of the remaining 12 fermentable substances. The flocculation behaviour of non-flocculent strain 116 and flocculent strain 201 cells was determined by a modified HeLMS test (10). The initial sedimenting rate of strain 116 cells in $0.002 \mathrm{M}$ $\mathrm{CaCl}_{2}, 22^{\circ} \mathrm{C}, \mathrm{pH} 6$, was characterized by a $\frac{1}{2}$ of 11.3 hours (time necessary to obtain $50 \%$ of the final supernatant volume when the cells sediment at an initial rate) and that of strain 201 cells by a $\frac{1}{2}$ of 1.2 hour determined under the same conditions.

All the common reagents were of analytical grade. Deionized water was used throughout. Trypsin from British Drug House, Poole, England, had not less than 0.54 Anson units per $\mathrm{g}$. Pronase and sodium dodecyl sulfate were obtained from Sigma Chem. Co., St. Louis, Mo., ${ }^{3} \mathrm{H}$ - and ${ }^{14} \mathrm{C}$-labelled I-fluoro-2,4dinitrobenzene from the Radiochemical Centre Ltd., Amersham, U.K.; $\beta$-mercaptoethanol from Fluka AG, Buchs, Switzerland; Sephadex G-100 (fine) and Sephadex G-25 (superfine) from Pharmacia Fine Chemicals AB, Uppsala, Sweden; Bio-Gel P-10 (100-200 mesh) from Bio-Rad Laboratories, Richmond, Calif.; purified antibodies from rabbits against barley and yeast antigens present in beer were a gift from Dr. J. HEJGAaRD, Dept. of Biochemistry and Nutrition, Technical University of Denmark, Lyngby.

\section{METHODS}

\subsection{Trypsin digestion and $\beta$-mercaptoethanol treatment}

The strains 116 and 201 cells received as suspensions in beer were left overnight at $4^{\circ} \mathrm{C}$. 
The supernatants were poured off and the residues washed 4 times with deionized water (about $7 \mathrm{ml}$ water per $\mathrm{g}$ of wet cells). The cells were centrifuged each time at $4^{\circ} \mathrm{C}$ in a refrigerated centrifuge at about $3000 \mathrm{~g}$ during 68 minutes. The washed cells were suspended in deionized water ( $2 \mathrm{ml}$ water per $\mathrm{g}$ of cells) and stirred magnetically. The initial $\mathrm{pH}$ of the cell suspensions was 4.1. Sufficient $1 \mathrm{M}-\mathrm{NaOH}$ was added to raise $\mathrm{pH}$ to 8.5 , an aliquot of $1 \%$ trypsin solution in $0.01 \mathrm{M}-\mathrm{HCl}$ was added to each stirred cell suspension $(0.3 \mathrm{mg}$ trypsin per $\mathrm{g}$ of wet cells) and the $\mathrm{pH}$ was maintained at $8.50 \pm 0.05$ by adding increments of $1 \mathrm{M}-\mathrm{NaOH}$. After 30 minutes another similar aliquot of the trypsin solution was added, the digestion continued at $22^{\circ} \mathrm{C}$ for a total of approximately two hours. The suspensions were centrifuged $\left(4^{\circ} \mathrm{C}\right.$, $3000 \mathrm{~g}, 7$ minutes) and washed once with water $(1 \mathrm{ml}$ per $\mathrm{g}$ of cells). The supernatants and the respective washes were combined and lyophilized (fractions 116-A and 201-A, Table I).

The residual cells were suspended in water $(1 \mathrm{ml}$ per gram of cells) and treated with $\beta$ mercaptoethanol (final concentration $1 \%$ ). The suspensions were left overnight at room temperature. Next day they were centrifuged $\left(4^{\circ} \mathrm{C}, 3000 \mathrm{~g}, 7\right.$ minutes) and washed twice with water $(1 \mathrm{ml}$ per $\mathrm{g})$. The supernatants and the respective washes were combined and lyophilized (fractions 116-B and 201-B). The cell residues were resuspended in water $(2 \mathrm{ml}$ per $\mathrm{g}$ ) and subjected to a second tryptic digestion under the same conditions as described for the first digestion. After centrifugation the supernatants and the corresponding washes were combined and lyophilized (fractions 116-C and $201-\mathrm{C}$ ).

The cell residues were treated according to a principle used by SMITH \& HALVORSON (18) for isolation of DNA from yeast cells and other microorganisms. After storage at $4^{\circ} \mathrm{C}$ for 4 days the residues were suspended in $0.15 \mathrm{M}-\mathrm{NaCl}-0.1$ M-EDTA-2\% SDS solution ${ }^{1)}$, pH 8.0 (1-2 ml per g), mixed occasionally during 30 minutes at room temperature, collected by centrifugation $\left(4^{\circ} \mathrm{C}, 3000 \mathrm{~g}, 8\right.$ minutes $)$ and frozen at $-20^{\circ} \mathrm{C}$. After thawing they were suspended in fresh $\mathrm{NaCl}$-EDTA-SDS solution (3-4 $\mathrm{ml} \mathrm{per} \mathrm{g}$ ) and incubated with occasional mixing during 4 hours at $45-47^{\circ} \mathrm{C}$. The suspensions were centrifuged $\left(20^{\circ} \mathrm{C}, 3000 \mathrm{~g}, 8\right.$ minutes), the residues washed twice with the same solution ( 2 $\mathrm{ml}$ per $\mathrm{g}$ ) followed by 3 washes with deionized water $(7-8 \mathrm{ml}$ per $\mathrm{g})$. The residues of extracted cells were lyophilized yielding fractions 116-D and 201-D.

\subsection{Sephadex G-100 gel filtration}

Lyophilized samples obtained from the first trypsin digestion, the $\beta$-mercaptoethanol treatment, and the second trypsin digestion of strain 116 and strain 201 cells were suspended separately in $20 \mathrm{ml} 0.05 \mathrm{M}-\mathrm{NaCl}$ during 1 hour and a small amount of insoluble material was removed by centrifugation. The supernatants were applied to a Sephadex G-100 (fine) column $(2.6 \times 96 \mathrm{~cm})$ equilibrated with $0.05 \mathrm{M}$ $\mathrm{NaCl}$ and maintained at $4^{\circ} \mathrm{C}$. The column was eluted with $0.05 \mathrm{M}-\mathrm{NaCl}(30 \mathrm{ml} / \mathrm{h})$. The transmittance at $280 \mathrm{~nm}$ of the eluate was monitored. The eluted fractions were analysed for carbohydrate content, ninhydrin colour (after alkaline hydrolysis), and for the presence of yeast and barley antigenic determinants by means of immuoelectrophoresis.

The column was calibrated with a mixture of $20 \mathrm{mg}$ samples of $\beta$-lactoglobulin (mol.wt. 37,000 ), bovine serum albumin (mol.wt. 66,000) and bovine $\gamma$-globulin (mol.wt. 160,000) dissolved in $20 \mathrm{ml} 0.05 \mathrm{M}-\mathrm{NaCl}$.

\subsection{Sephadex G-25 gel filtration}

Lyophilized fractions from Sephadex G-100 chromatography were suspended in $15 \mathrm{ml} 0.05$ $\mathrm{M}-\mathrm{NaCl}$ during 1 hour, the insoluble material

1) Abbreviations: SDS = sodium dodecyl sulfate; EDTA = ethylene diamine tetraacetic acid, disodium salt: FDNB = I-fluoro-2,4-dinitrobenzene; NaCl-EDTA-SDS $=0.15 \mathrm{M}-\mathrm{NaCl}-0.1 \mathrm{M}-\mathrm{EDTA}-2 \%$ SDS solution; mol.wt. $=$ molecular weight. 
was removed by centrifugation. The weights were determined after drying at $110^{\circ} \mathrm{C}$ for 2 hours. The soluble portions were applied to a Sephadex G-25 (superfine) column $(2 \times 59 \mathrm{~cm})$ equilibrated with $0.05 \mathrm{M}-\mathrm{NaCl}$. The column was operated at $4{ }^{\circ} \mathrm{C}$ with a flow of $14 \mathrm{ml} / \mathrm{h}$ of 0.05 $\mathrm{M}-\mathrm{NaCl}$. The transmittance at $280 \mathrm{~nm}$ of the eluate was monitored.

The column was calibrated with a mixture of $5.0 \mathrm{mg} \beta$-chain of insulin (mol.wt. 3,428), $8.0 \mathrm{mg}$ $\alpha$-chain of insulin (mol.wt. 2,385) and $1.2 \mathrm{mg}$ vitamin $B_{12}$ (mol.wt. 1,357).

\subsection{Immunochemical analysis}

Fused rocket immunoelectrophoresis with an intermediate gel was performed essentially as described by AXELSEN et al. (3). The intermediate gel contained a protein-rich beer fraction (fraction $X$ ) previously studied by Hejgaard \& Sørensen (9). Purified rabbit antibodies against fraction $X$ were the same as those previously used (9). Aliquots $(5 \mu \mathrm{l})$ of every third fraction from the Sephadex G-100 gel filtrations were applied in sample wells punched out in a $1 \%$ agarose gel containing electrophoresis buffer (73mM-Tris, $24.5 \mathrm{~mm}$ barbital, $0.36 \mathrm{~mm}$-calcium lactate, $\mathrm{pH} 8.6$ ). Immunoelectrophoresis was performed for 18 hours at $2 \mathrm{~V} / \mathrm{cm}$. The temperature was maintained at $14^{\circ} \mathrm{C}$. Excess of antibodies was washed out with $0.1 \mathrm{M}-\mathrm{NaCl}$, the plate was dried and the precipitates of antigens with antibodies stained with Coomassie Blue R-250 as described by A XELSEN et al. (3).

\subsection{Pronase digestion of ${ }^{3} \mathrm{H}$ - and ${ }^{14} \mathrm{C}$-labelled yeast cell residues}

Cell residues obtained after trypsin, $\beta$ mercaptoethanol and NaCl-EDTA-SDS treatment were labelled with radioactive 1-fluoro2,4-dinitrobenzene (FDNB). Cell residues of strain 116 cells were suspended in water $(4 \mathrm{~g}$ in $40 \mathrm{ml}$ ) and the suspension adjusted to $\mathrm{pH} 10$ with $1 \mathrm{M}-\mathrm{NaOH}$. The ethanolic solution $(1 \mathrm{ml})$ of ${ }^{3} \mathrm{H}$-FDNB $(0.23 \mathrm{mg}, 1.22 \mu$ moles, $250 \mu \mathrm{Ci})$ was added and the reaction mixture stirred for 4 hours at room temperature. Similarly, strain 201 cell residues were suspended in $\mathrm{H}_{2} \mathrm{O}(2 \mathrm{~g}$ in
$20 \mathrm{ml}$ ), adjusted to $\mathrm{pH} 10$ and treated with $1 \mathrm{ml}$ ethanolic solution of ${ }^{14} \mathrm{C}$-FDNB $(0.44 \mathrm{mg}, 2.38$ $\mu$ moles, $50 \mu \mathrm{Ci}$ ) during the same period of time. The reaction mixtures were centrifuged, washed 5 times with deionized water and the residues stored at $-20^{\circ} \mathrm{C}$.

The labelled residues were combined and suspended in $60 \mathrm{ml}$ of $0.1 \mathrm{M}$-Tris/ $\mathrm{HCl}$ buffer, $\mathrm{pH}$ 8.0 , containing $0.01 \mathrm{M}-\mathrm{CaCl}_{2}$. The reaction flask was placed in a water bath maintained at $37 \pm$ $1{ }^{\circ} \mathrm{C}$ and $100 \mathrm{mg}$ of pronase was added to a stirred suspension. After 16 hours another 100 $\mathrm{mg}$ portion of pronase was added and the digestion continued for a total of 24 hours. The reaction was terminated by lowering $\mathrm{pH}$ to 4.0 with glacial acetic acid. The reaction mixture was centrifuged and the residues washed 3 times with water. The first supernatant and the washes were combined and lyophilized.

\subsection{Bio-Gel P-10 gel filtration}

The lyophilized supernatant $(2.6 \mathrm{~g})$ from the pronase digestion was redissolved in $20 \mathrm{ml} 0.1$ $\mathrm{M}$-acetic acid and centrifuged. The supernatant was placed on a Bio-Gel P-10 (100-200 mesh) column $(2.6 \times 96 \mathrm{~cm})$ equilibrated with $0.1 \mathrm{M}$ acetic acid. The column was eluted with $0.1 \mathrm{M}$ acetic acid at $4^{\circ} \mathrm{C}$ at a flow rate of $23 \mathrm{ml} / \mathrm{h}$. Fractions were collected and analysed for ninhydrin colour, carbohydrate content, and radioactivity.

The column was calibrated with $\beta$ lactoglobulin, ribonuclease, pig insulin, $\beta$-chain of insulin, vitamin $B_{12}$ and reduced glutathione.

\subsection{Analytical procedures}

Amino acid analysis was carried out according to the procedure described by SPACKMAN et al. (19). Samples containing about $100 \mu \mathrm{g}$ of protein were hydrolyzed for 24 hours in $6 \mathrm{~N}-\mathrm{HCl}$ at $110^{\circ} \mathrm{C}$ in sealed evacuated tubes. The hydrolysates were analysed by a highpressure Durrum Model D-500 automatic amino acid analyzer. The results were not corrected for hydrolysis losses.

The total content of carbohydrates was determined by the phenol-sulfuric acid procedure described by ASHWELL (2) and was 
reported as glucose. The absorbance was read at $490 \mathrm{~nm}$.

Ninhydrin colour determinations were performed on $10 \mu \mathrm{l}$ aliquots after alkaline hydrolysis for 2 hours in $150 \mu 113.5 \mathrm{M}-\mathrm{NaOH}$ at $110^{\circ} \mathrm{C}$ in an oven according to the procedure described by HiRs (11).

Purine and pyrimidine analysis was performed essentially as described by WYATT (23). To a 20-30 mg sample of lyophilized yeast cell residues in a Pyrex centrifuge tube was added $400 \mu \mathrm{l} 72 \%$ perchloric acid. After careful mixing, the test tube was covered with a glass bead and heated for 1 hour in boiling water. After cooling, $10 \mathrm{ml}$ of deionized water was added, the contents mixed, centrifuged, and the supernatant used for determination of UVspectrum (200-400 nm). From the absorbance at $260 \mathrm{~nm}$ the concentration of purine and pyrimidine bases in solution was calculated using an average extinction coefficient $\varepsilon_{\max }=$ 11,400 litre $\cdot$ mole $^{-1} \cdot \mathrm{cm}^{-1}$.

Phosphorus analysis was carried out according to the procedure of BARTLETT (5). A sample $(2 \mathrm{ml})$ of the supernatant from perchloric acid hydrolysis was placed in a Pyrex centrifuge tube. $0.05 \mathrm{ml} 5 \mathrm{M}-\mathrm{H}_{2} \mathrm{SO}_{4}$ was added and the tube heated in an oven at $150-160^{\circ} \mathrm{C}$ for
3 hours. 2 drops of $30 \%$ hydrogen peroxide were added and heating continued for additional 1.5 hours. After cooling $4.4 \mathrm{ml}$ deionized water and $0.2 \mathrm{ml} 5 \%$ ammoniummolybdate were added. After mixing, $0.2 \mathrm{ml}$ Fiske-SubbaRow reagent was added, and the contents mixed again. The tubes were covered with glass-beads and heated for 7 minutes in a boiling water bath. The absorbance was read at $660 \mathrm{~nm}$ against deionized water.

Determination of radioactivity was performed with $0.1 \mathrm{ml}$ aliquots of chromatographic fractions by mixing with $10 \mathrm{ml}$ of Packard Dimilume-30 liquid scintillation mixture and counting for 5 minutes in a Beckman LS $3155 \mathrm{~T}$ Liquid Scintillation Counter. Internal ${ }^{3} \mathrm{H}$ and ${ }^{14} \mathrm{C}$ standards were used to correct for the counting efficiency losses in the unknown samples. The correction factors were 2.4 for ${ }^{3} \mathrm{H}$ c.p.m. and 1.33 for ${ }^{14} \mathrm{C}$ c.p.m., respectively.

\section{RESULTS}

\subsection{Trypsin digestion and treatment of yeast cells with $\beta$-mercaptoethanol}

Trypsin digestion of carefully washed strain 116 and strain 201 yeast cells released a con-

Table I

Trypsin digestion and $\beta$-mercaptoethanol treatment of yeast cells. The weight of the lyophilized fractions has been calculated on the basis of $100 \mathrm{~g}$ of washed and centrifuged cells as a starting material. Experimental conditions are described in the text.

\begin{tabular}{l|c|c|c|c}
\hline & Fraction & $\begin{array}{c}\text { Weight after lyoph. } \\
\text { (g/100 g wet cells) }\end{array}$ & $\begin{array}{c}\text { Carbohydrate } \\
\text { content } \\
\text { (weight-\%) }\end{array}$ & $\begin{array}{c}\text { Protein b) } \\
\text { content } \\
\text { (weight-\%) }\end{array}$ \\
\hline S.carlsbergensis (strain 116) & $116-\mathrm{A}$ & 1.58 & 14 & 34 \\
First trypsin digestion & $116-\mathrm{B}$ & 0.90 & 17 & 34 \\
$\begin{array}{l}\beta-\text { mercaptoethanol treatm. } \\
\text { Second trypsin digestion }\end{array}$ & $116-\mathrm{C}$ & 1.06 & 12 & 38 \\
Cell residues & $116-\mathrm{D}$ & 7.95 & 81 & 20 \\
S.carlsbergensis (strain 201) & & & & \\
First trypsin digestion & $201-\mathrm{A}$ & 1.91 & 13 & 25 \\
$\beta$ 3-mercaptoethanol treatm. & $201-\mathrm{B}$ & 0.96 & 23 & 24 \\
Second trypsin digestion & $201-\mathrm{C}$ & 1.11 & 10 & 35 \\
Cell residues & 201-D & 10.19 & 83 & 18 \\
\hline
\end{tabular}

a) Based on the areas under carbohydrate curves of Sephadex G-100 gel filtration.

b) Calculated from the amino acid analyses (Table II). 
siderable amount of material into solution. The results are listed in Table $I$ and it can be seen that the amount of solubilized material (fraction 201-A) obtained from the flocculent strain 201 cells was $20 \%$ higher than from the nonflocculent strain 116. The carbohydrate content of the two fractions were about equal (13\%).

The trypsin-treated yeast cells were further subjected to $\beta$-mercaptoethanol treatment releasing additional quantities of material into the supernatant. In principle, this material (fractions 116-B and 201-B) may originate as a result of the previous trypsin digestion, such as a tryptic fragment attached by disulfide bonds to the cell wall being released by reduction of the disulfide bonds by the $\beta$-mercaptoethanol treatment, or it may be released from the cell wall quite independently of the previous trypsin digestion (6). The amount of material was similar in the two $\beta$-mercaptoethanol fractions but the carbohydrate content was higher for strain 201 cells $(23 \%)$, than for strain 116 cells (17\%).

A second trypsin digestion of the $\beta$ mercaptoethanol-treated cells gave rise to two additional soluble fractions, 116-C and 201-C. The weights and the carbohydrate contents of these fractions from the two types of cells were almost the same. The residual cells, after the second trypsin treatment, were isolated and subjected to $\mathrm{NaCl}$-EDTA-SDS-treatment and to a cycle of freezing and thawing as described in section 3.1. This was done in the hope of obtaining cell envelopes free of intracellular material. The final quantities of the salt-free lyophilized cell residues were $12 \mathrm{~g}$ (strain 116 cells) and $17 \mathrm{~g}$ (strain 201 cells) and the carbohydrate content was high, about $82 \%$ of dry weight (fractions 116-D and 201-D). A control analysis for purine and pyrimidine bases as well as for total phosphate demonstrated 116-D to contain $6.4 \%$ nucleic acids and $1.8 \%$ phosphate based on dry weight of cell residues whereas the fraction 201-D obtained from 201 cells had $5.6 \%$ nucleic acids and $1.4 \%$ phosphate based on dry weight of cell residues. This indicated the presence of nucleic acids in these preparations and thus that one cycle of $\mathrm{NaCl}$-EDTA-SDS-treatment and freezethawing was not sufficient to liberate completely intracellular components from these strains of yeast.

All fractions from the non-flocculent strain 116 had a higher protein content, as calculated from amino acid analyses, than the corresponding fractions from the flocculent strain.

Table II

Relative amino acid composition of tryptic and $\beta$-mercaptoethanol fractions. Fractions are designated as shown in Table I. Hydrolysis conditions are described in the text. Results are not corrected for hydrolysis losses. Amino acid residues are normalized with respect to Glx content.

\begin{tabular}{|c|c|c|c|c|c|c|c|c|}
\hline \multirow[t]{2}{*}{ A mino acid } & \multicolumn{8}{|c|}{ Fraction } \\
\hline & $116-A$ & 201-A & 116-B & 201-B & $116-C$ & $201-C$ & 116-D & 201-D \\
\hline$\overline{A s x}$ & 52 & 62 & 61 & 71 & 64 & 85 & 99 & 99 \\
\hline Thr & 27 & 31 & 35 & 44 & 33 & 44 & 77 & 77 \\
\hline Ser & 38 & 45 & 44 & 59 & 39 & 49 & 111 & 106 \\
\hline Glx & 100 & 100 & 100 & 100 & 100 & 100 & 100 & 100 \\
\hline Pro & 39 & 44 & 51 & 88 & 42 & 42 & 45 & 46 \\
\hline Gly & 54 & 62 & 59 & 85 & 54 & 70 & 92 & 89 \\
\hline Ala & 60 & 82 & 138 & 237 & 67 & 94 & 108 & 105 \\
\hline Val & 31 & 36 & 38 & 45 & 41 & 47 & 64 & 64 \\
\hline Met & 7 & 7 & 8 & 7 & 10 & 10 & 14 & 14 \\
\hline Ile & 20 & 25 & 27 & 34 & 28 & 37 & 55 & 56 \\
\hline Leu & 36 & 41 & 44 & 49 & 52 & 60 & 85 & 85 \\
\hline Tyr & 15 & 16 & 19 & 19 & 18 & 20 & 29 & 30 \\
\hline Phe & 16 & 18 & 20 & 22 & 22 & 25 & 38 & 39 \\
\hline $\mathrm{His}$ & 10 & 12 & 11 & 14 & 12 & 16 & 17 & 18 \\
\hline Lys & 26 & 36 & 30 & 43 & 34 & 57 & 85 & 85 \\
\hline Arg & 22 & 26 & 25 & 29 & 26 & 32 & 48 & 49 \\
\hline
\end{tabular}


Relative amino acid compositions of the tryptic and of the mercaptoethanol fractions as well as of the NaC1-EDTA-SDS-treated cell residues are given in Table II. The values for all amino acids have been normalized with respect to the glutamic acid content. It can be seen that the amino acid composition of fraction 116-A and 201-A (obtained after first trypsin treatment) was different. Fraction 201-A from strain 201 had a higher content of Asx, Ser, Ala and Lys than the fraction from strain 116. Similarly, the content of these amino acids was higher in fraction 201-B (obtained after $\beta$-mercaptoethanol treatment) than in fraction 116-B. In addition, the content of Pro was nearly twice as high in the former fraction as in the latter fraction. The second trypsin treatment of the two types of yeast released material whose amino acid composition was also different. The two fractions $201-\mathrm{C}$ and 116-C differed in the content of the same amino acids (except Pro) as did fractions 201-B and 116-B. In contrast, the amino acid composition of the NaCl-EDTA-
SDS-treated cells was similar. Both fractions 201-D and 116-D had a high content of Asx, Ser, Glu, Gly, Ala, Leu, and Lys.

\subsection{Sephadex G-100 gel filtration}

Fractions containing solubilized material resulting from tryptic digestions and $\beta$ mercaptoethanol treatment were fractionated on a Sephadex G-100 column as described in section 3.2. The results of these gel filtration experiments are summarized in Figure 1 and in Table III. The eluted material from the column was found essentially in two regions, one of high molecular weight ranging from 40,000 to 200,000 and the other of molecular weight below 4,000. Very little material of intermediate molecular weight was eluted from the column. The largest amount of material was found in the region of low molecular weight. As seen from Figure 1, carbohydrate and ninhydrin analyses revealed some differences between fractions obtained from non-flocculent and flocculent

\section{Table III}

Sephadex G-100 gel filtration. Samples (soluble part) taken for gel filtration are shown in Table I. Conditions of gel filtration, calibration of the column and immunochemical characterization of the fractions are described in the text.

\begin{tabular}{|c|c|c|c|c|c|c|}
\hline \multirow{2}{*}{$\begin{array}{l}\text { Sample and } \\
\text { weight (g) }\end{array}$} & \multirow[b]{2}{*}{ Fraction } & \multirow{2}{*}{$\begin{array}{l}\text { Weight }{ }^{\text {a) }} \\
\text { (g) }\end{array}$} & \multirow{2}{*}{$\begin{array}{c}\text { Approx. } \\
\text { mol. wt. } \\
\times 10^{-3}\end{array}$} & \multirow{2}{*}{$\begin{array}{c}\text { Carbohydrate } \\
\text { content } \\
\text { (weight-\%) }\end{array}$} & \multicolumn{2}{|c|}{ Antigenic determinants } \\
\hline & & & & & Yeast & Barley \\
\hline $\begin{array}{l}116-\mathrm{A} \\
(2.40)\end{array}$ & $\begin{array}{l}116-A-1 \\
116-A-2\end{array}$ & $\begin{array}{l}0.25 \\
1.36\end{array}$ & $\begin{array}{r}40-200 \\
4\end{array}$ & 25 & + & + \\
\hline $\begin{array}{l}116-\mathrm{B} \\
(1.34)\end{array}$ & $\begin{array}{l}116-\mathrm{B}-1 \\
116-\mathrm{B}-2\end{array}$ & $\begin{array}{l}0.14 \\
0.80\end{array}$ & $\begin{array}{r}40-200 \\
4\end{array}$ & 23 & + & - \\
\hline $\begin{array}{l}116-C \\
(1.62)\end{array}$ & $\begin{array}{l}116-C-1 \\
116-C-2\end{array}$ & $\begin{array}{l}0.26 \\
1.04\end{array}$ & $\begin{array}{r}40-200 \\
4\end{array}$ & 14 & $\begin{array}{l}+ \\
-\end{array}$ & + \\
\hline $\begin{array}{l}201-\mathrm{A} \\
(2.99)\end{array}$ & $\begin{array}{l}201-A-1 \\
201-A-2\end{array}$ & $\begin{array}{l}0.18 \\
2.25\end{array}$ & $\begin{array}{r}40-200 \\
4\end{array}$ & 41 & + & + \\
\hline $\begin{array}{l}201-\mathrm{B} \\
(1.54)\end{array}$ & $\begin{array}{l}201-B-1 \\
201-B-2\end{array}$ & $\begin{array}{l}0.13 \\
0.64\end{array}$ & $\begin{array}{r}40-200 \\
4\end{array}$ & 32 & + & - \\
\hline $\begin{array}{l}201-C \\
(1.80)\end{array}$ & $\begin{array}{l}201-C-1 \\
201-C-2\end{array}$ & $\begin{array}{l}0.13 \\
1.38\end{array}$ & $\begin{array}{r}40-200 \\
4\end{array}$ & 15 & + & + \\
\hline
\end{tabular}

a) Corrected for salt content.

b) Not corrected for salt content. 


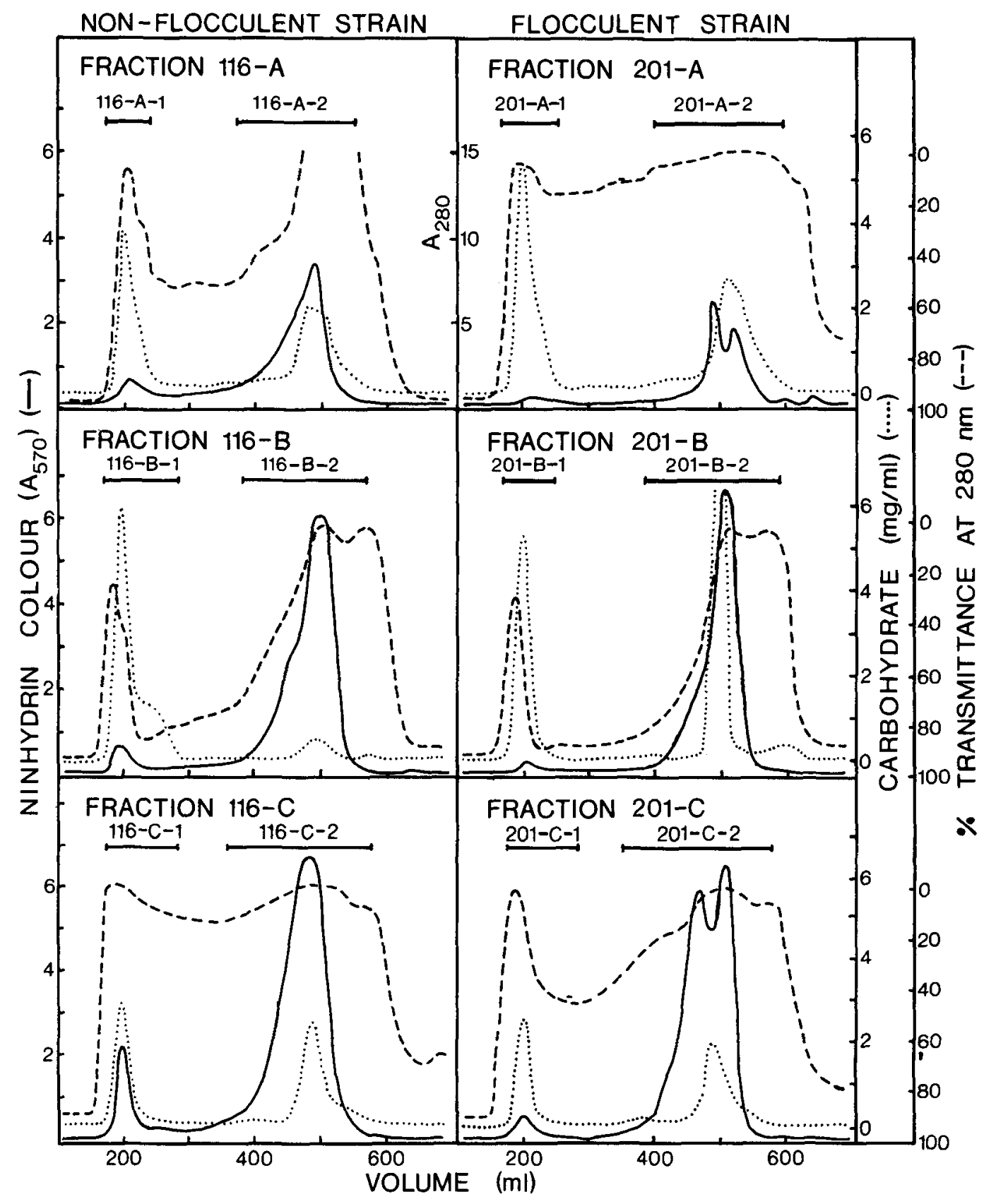

Figure 1. Gel chromatography on Sephadex G-100 of the first tryptic digests, $\beta$-mercaptoethanol fractions and the second tryptic digests of yeast cells. Fractions (see Table I) were dissolved in $20 \mathrm{ml} 0.05 \mathrm{M}-\mathrm{NaCl}$ and applied to the column $(2.6 \times 96 \mathrm{~cm})$. Fractions $(7.5 \mathrm{ml})$ were collected and analysed for absorbance or transmittance at $280 \mathrm{~nm}(----)$, ninhydrin colour yield after alkaline hydrolysis (-), and for carbohydrate content (.....).

cells. Generally, high mol.wt. material (fractions 116-A-1, 116-B-1 and 116-C-1) from non-flocculent strain 116 cells had a higher content of peptides and lower content of carbohydrate than the corresponding material from flocculent strain 201 cells. Differences were also observed in the low molecular weight fractions. The low mol.wt. material of fractions 
201-A and 201-C was resolved into two peaks (ninhydrin colour) whereas that of fractions 116-A and 116-C was eluted as a single peak.

Rocket-line immunoelectrophoretic experiments of effluent fractions from gel filtration, using antibodies against beer fraction $X$ and fraction $X$ antigens (9) in the intermediate gel, between the sample-containing wells and the antibody-containing gel, revealed the presence of yeast antigenic determinants in the high mol.wt. material of all fractions obtained from non-flocculent and flocculent yeasts (Table III). Furthermore, it was found that fractions 116-A and 201-A resulting from the first trypsin treatment and fractions $116-\mathrm{C}$ and $201-\mathrm{C}$ resulting from the second trypsin treatment had in their high mol.wt. components antigenic determinants, which showed immunochemical identity with a fraction $\mathrm{X}$ antigen. This antigen had previously been shown to originate from the barley used for the production of wort, which was used for the propagation of the yeast strains. This type of antigenic determinants was not found in the fractions 116-B and 201-B obtained after $\beta$-mercaptoethanol treatment. The high mol.wt material from the non-flocculent cells contained from 3 to 10 times more of this antigenic component than the material from the flocculent cells.

\section{Table IV}

Sephadex G-25 gel filtration. Samples taken for gel filtration are listed in Table III. Experimental conditions and column calibration are described in the text. The weights in parentheses are too high because this material after lyophilization was viscous and probably had a large content of water.

\begin{tabular}{|c|c|c|c|c|c|}
\hline $\begin{array}{l}\text { Sample and } \\
\text { weight }(\mathrm{g})\end{array}$ & Fraction & $\begin{array}{l}\text { Weight }{ }^{\text {a) }} \\
\text { (g) }\end{array}$ & $\begin{array}{l}\text { Approx. } \\
\text { mol. wt. } \\
x 10^{-3}\end{array}$ & $\begin{array}{c}\text { Carbohydrate }{ }^{\text {b) }} \\
\text { content } \\
\text { (weight-\%) }\end{array}$ & $\begin{array}{l}\text { Peptide }{ }^{\text {b) }} \\
\text { content } \\
\text { (weight-\%) }\end{array}$ \\
\hline $\begin{array}{l}116-A-2 \\
(1.33)\end{array}$ & $\begin{array}{l}\text { I } \\
\text { II } \\
\text { III } \\
\text { IV }\end{array}$ & $\begin{array}{c}0.13 \\
0.13 \\
(1.46) \\
0.65\end{array}$ & $\begin{array}{l}3.0 \\
2.1 \\
1.4 \\
1.0\end{array}$ & $\begin{array}{l}7.1 \\
4.0 \\
4.0 \\
6.6\end{array}$ & $\begin{array}{r}28 \\
62 \\
7 \\
2\end{array}$ \\
\hline $\begin{array}{l}116-\mathrm{B}-2 \\
(0.79)\end{array}$ & $\begin{array}{l}\text { I } \\
\text { II } \\
\text { III }\end{array}$ & $\begin{array}{c}0.03 \\
0.11 \\
(0.87)\end{array}$ & $\begin{array}{l}3.0 \\
2.5 \\
1.5\end{array}$ & $\begin{array}{l}3.0 \\
1.5 \\
0.8\end{array}$ & $\begin{array}{l}21 \\
36 \\
13\end{array}$ \\
\hline $\begin{array}{l}116-C-2 \\
(1.01)\end{array}$ & $\begin{array}{l}\text { I } \\
\text { II } \\
\text { III } \\
\text { IV }\end{array}$ & $\begin{array}{c}0.08 \\
0.16 \\
(0.59) \\
(0.53)\end{array}$ & $\begin{array}{l}3.7 \\
2.4 \\
1.3 \\
1.0\end{array}$ & $\begin{array}{l}4.9 \\
5.0 \\
3.7 \\
2.1\end{array}$ & $\begin{array}{r}23 \\
43 \\
16 \\
8\end{array}$ \\
\hline $\begin{array}{l}201-\mathrm{A}-2 \\
(2.20)\end{array}$ & $\begin{array}{l}\text { I } \\
\text { II } \\
\text { III } \\
\text { IV }\end{array}$ & $\begin{array}{c}0.12 \\
0.13 \\
0.86 \\
(0.94)\end{array}$ & $\begin{array}{l}3.8 \\
1.9 \\
1.7 \\
1.0\end{array}$ & $\begin{array}{l}8.4 \\
4.2 \\
4.5 \\
1.8\end{array}$ & $\begin{array}{r}26 \\
47 \\
15 \\
6\end{array}$ \\
\hline $\begin{array}{l}201-B-2 \\
(0.63)\end{array}$ & $\begin{array}{l}\text { I } \\
\text { II } \\
\text { III }\end{array}$ & $\begin{array}{c}0.01 \\
0.06 \\
(1.07)\end{array}$ & $\begin{array}{l}3.0 \\
2.5 \\
1.4\end{array}$ & $\begin{array}{l}3.8 \\
1.8 \\
0.7\end{array}$ & $\begin{array}{l}20 \\
34 \\
10\end{array}$ \\
\hline $\begin{array}{l}201-C-2 \\
(1.37)\end{array}$ & $\begin{array}{l}\text { I } \\
\text { II } \\
\text { III }\end{array}$ & $\begin{array}{c}0.14 \\
0.19 \\
(1.08)\end{array}$ & $\begin{array}{l}3.3 \\
2.1 \\
1.2\end{array}$ & $\begin{array}{l}5.5 \\
8.9 \\
1.4\end{array}$ & $\begin{array}{r}29 \\
37 \\
7\end{array}$ \\
\hline
\end{tabular}

a) Corrected for salt content.

b) Not corrected for salt content. Peptide content calculated from amino acid analyses (Table V and VI). 
4.3 Sephadex G-25 gel filtration of low molecular weight material

Sephadex G-100 fractions containing low mol.wt. material were further fractionated on Sephadex G-25 (superfine) column using 0.05 $\mathrm{M}-\mathrm{NaCl}$ as the solvent. The elution patterns from the six gel filtration experiments are shown in Figure 2. The resolution of carbohydrate-positive peaks is much better on this column, but the resolutions of the ninhydrinpositive peaks (with the exception of fraction 201-A-2) are only slightly improved. The weights of the lyophilized material corresponding to the various fractions are

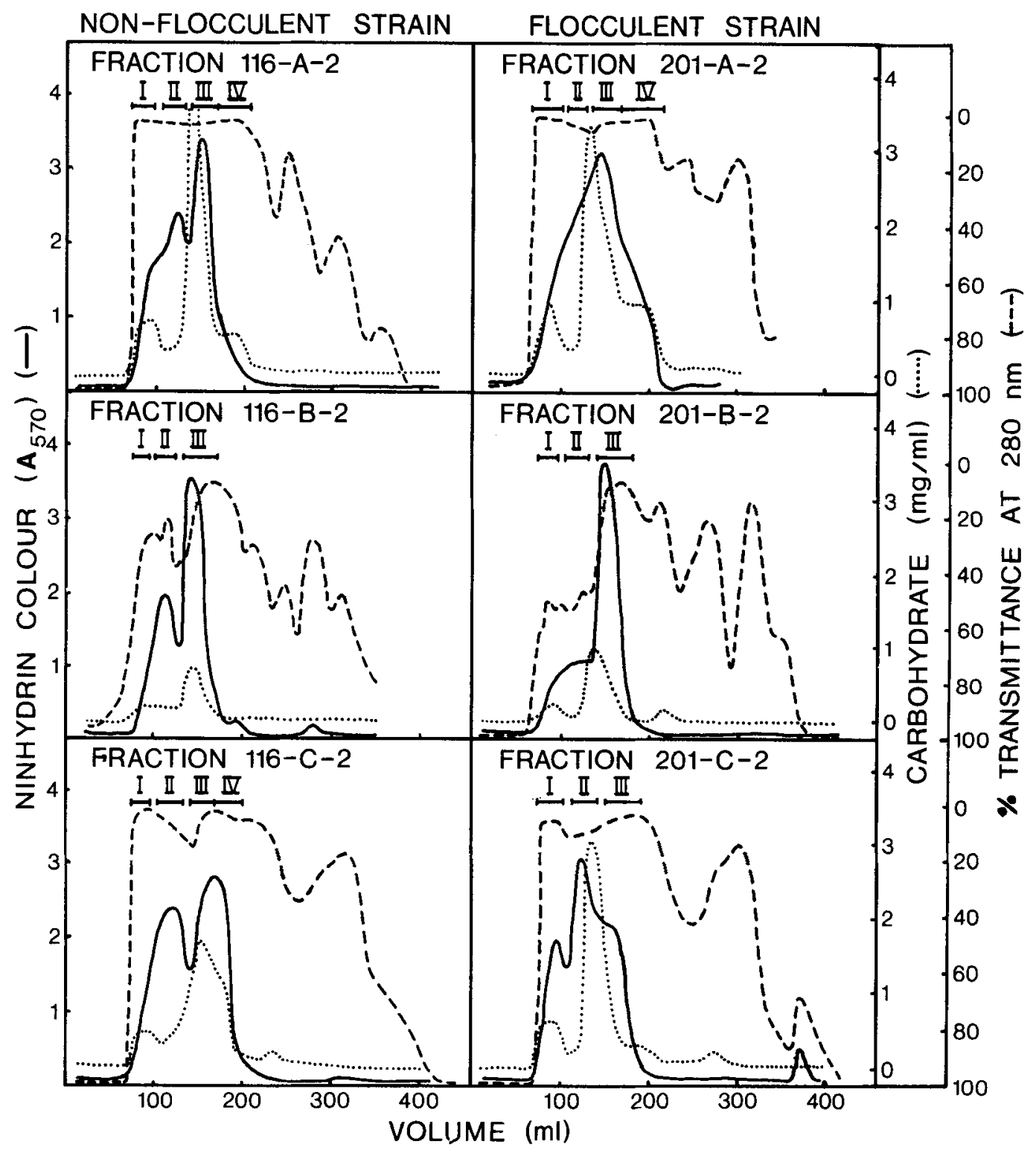

Figure 2. Gel chromatography on Sephadex G-25 of low mol.wt. fractions resulting from the first tryptic digests, $\beta$-mercaptoethanol treatments and from the second tryptic digests of yeast cells. Fractions (see Table III) were dissolved in $15 \mathrm{ml} 0.05 \mathrm{M}-\mathrm{NaCl}$ and applied to the Sephadex column $(2 \times 59 \mathrm{~cm}) .4 .7 \mathrm{ml}$ fractions were collected and analysed for transmittance at $280 \mathrm{~nm}(---)$, ninhydrin colour yield after alkaline hydrolysis (- - , and for total carbohydrate (....). 
recorded in Table IV. The residues obtained after lyophilization of certain fractions were viscous and, therefore, their weights (enclosed in parentheses) do not represent the weights of dry residues. The approximate molecular weights of the various fractions ranged from 3,800 down to less than 1,000 . Most of the material was found in the range between 1,000

\section{Table V}

Relative amino acid composition of Sephadex G-25 gel filtration fractions from S.carlsbergensis (strain 116) cells. Fractions are designated as shown in Table IV. Conditions of acid hydrolysis are described in text. Amounts of amino acid residues are normalized with respect to Glx which is taken as 100 .

\begin{tabular}{|c|c|c|c|c|c|c|c|c|c|c|c|}
\hline & \multicolumn{4}{|c|}{$116-\mathrm{A}-2$} & \multicolumn{3}{|c|}{$116-B-2$} & \multicolumn{4}{|c|}{$116-C-2$} \\
\hline & I & II & III & IV & I & II & III & I & II & III & IV \\
\hline Asx & 80 & 72 & 31 & 84 & 83 & 89 & 33 & 81 & 88 & 59 & 58 \\
\hline Thr & 32 & 33 & 13 & 38 & 43 & 42 & 23 & 38 & 42 & 34 & 36 \\
\hline Ser & 35 & 38 & 21 & 64 & 45 & 46 & 27 & 40 & 46 & 35 & 41 \\
\hline Glx & 100 & 100 & 100 & 100 & 100 & 100 & 100 & 100 & 100 & 100 & 100 \\
\hline Pro & 42 & 39 & 16 & 62 & 66 & 54 & 41 & 55 & 47 & 31 & 29 \\
\hline Gly & 63 & 58 & 40 & 363 & 60 & 64 & 51 & 54 & 56 & 60 & 82 \\
\hline Ala & 41 & 46 & 108 & 89 & 54 & 62 & 270 & 52 & 58 & 106 & 126 \\
\hline Val & 39 & 38 & 22 & 50 & 47 & 51 & 28 & 45 & 48 & 45 & 44 \\
\hline Met & 8 & 8 & 7 & 21 & 9 & 10 & 7 & 10 & 10 & 13 & 18 \\
\hline Ile & 24 & 26 & 15 & 35 & 30 & 32 & 23 & 31 & 34 & 30 & 31 \\
\hline Leu & 44 & 41 & 24 & 56 & 52 & 54 & 38 & 55 & 58 & 57 & 60 \\
\hline Tyr & 12 & 9 & 10 & 296 & 12 & 12 & 5 & 13 & 11 & 20 & 49 \\
\hline Phe & 13 & 11 & 10 & 288 & 11 & 13 & 10 & 15 & 16 & 25 & 58 \\
\hline $\mathrm{His}$ & 10 & 9 & 6 & 77 & 8 & 12 & 8 & 8 & 10 & 14 & 25 \\
\hline Lys & 24 & 41 & 15 & 23 & 26 & 51 & 17 & 22 & 50 & 41 & 32 \\
\hline Arg & 20 & 17 & 21 & 90 & 14 & 20 & 27 & 14 & 19 & 37 & 62 \\
\hline
\end{tabular}

Table VI

Relative amino acid composition of Sephadex G-25 gel filtration fractions from S.carlsbergensis (strain 201) cells. Fractions are designated as shown in Table IV. Conditions of acid hydrolysis are described in text. Amounts of amino acid residues are normalized with respect to Glx which is taken as 100 .

\begin{tabular}{|c|c|c|c|c|c|c|c|c|c|c|}
\hline & \multicolumn{4}{|c|}{$201-A-2$} & \multicolumn{3}{|c|}{ 201-B-2 } & \multicolumn{3}{|c|}{$201-C-2$} \\
\hline & I & II & III & IV & I & II & III & I & II & III \\
\hline As $x$ & 87 & 77 & 46 & 59 & 98 & 102 & 49 & 103 & 105 & 71 \\
\hline Thr & 38 & 37 & 22 & 32 & 48 & 50 & 36 & 47 & 51 & 48 \\
\hline Ser & 39 & 42 & 39 & 55 & 52 & 57 & 47 & 50 & 60 & 49 \\
\hline Glx & 100 & 100 & 100 & 100 & 100 & 100 & 100 & 100 & 100 & 100 \\
\hline Pro & 46 & 38 & 39 & 61 & 53 & 47 & 134 & 45 & 42 & 50 \\
\hline Gly & 63 & 59 & 53 & 146 & 61 & 76 & 95 & 59 & 69 & 123 \\
\hline Ala & 45 & 55 & 113 & 186 & 61 & 77 & (395) & 64 & 81 & 205 \\
\hline Val & 43 & 44 & 28 & 44 & 46 & 58 & 47 & 55 & 56 & 46 \\
\hline Met & 8 & 9 & 8 & - & 10 & 8 & 7 & 11 & 13 & 18 \\
\hline Ile & 28 & 31 & 20 & 33 & 32 & 38 & 36 & 41 & 42 & 36 \\
\hline Leu & 48 & 50 & 34 & 54 & 51 & 58 & 52 & 61 & 74 & 65 \\
\hline Tyr & 12 & 9 & 13 & 57 & 9 & 12 & 5 & 13 & 18 & 73 \\
\hline Phe & 14 & 13 & 15 & 62 & 8 & 16 & 22 & 19 & 26 & 74 \\
\hline $\mathrm{His}$ & 8 & 8 & 10 & 33 & 11 & 17 & 11 & 10 & 16 & 38 \\
\hline Lys & 25 & 55 & 38 & 39 & 42 & 78 & 21 & 32 & 111 & 44 \\
\hline Arg & 14 & 18 & 29 & 64 & 9 & 22 & 36 & 9 & 34 & 89 \\
\hline
\end{tabular}




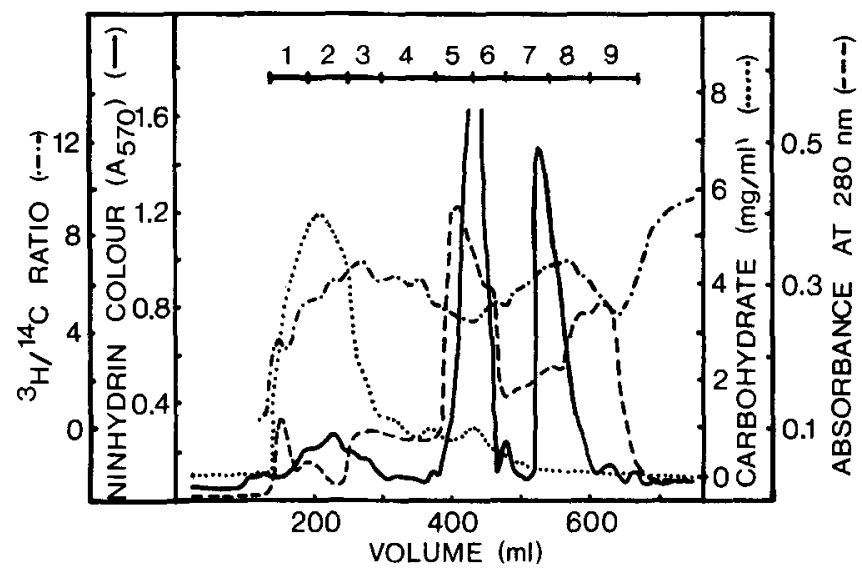

Figure 3. Gel chromatography on Bio-Gel P-10 of a pronase digest of combined ${ }^{3} \mathrm{H}$-labelled 116 cell residues and ${ }^{14} \mathrm{C}$-labelled 201 cell residues. Strain 116 yeast cell residue after trypsin- $\beta$-mercaptoethanoltrypsin and NaCl-EDTA-SDS-treatment were lightly labelled with ${ }^{3} \mathrm{H}$-FDNB. Strain 201 yeast cell residues after an identical treatment as strain 116 cells were lightly labelled with ${ }^{14} \mathrm{C}$-FDNB. The labelled cell residues were combined, digested with pronase and the resulting soluble fraction applied to the column $(2.6 \times 96 \mathrm{~cm})$. The effluent fractions $(5.8 \mathrm{ml})$ were analysed for absorbance at $280 \mathrm{~nm}$ (----), ninhydrin colour yield after alkaline hydrolysis (-), total carbohydrate content $(\cdots .$.$) , and for the ratio \left({ }^{3} \mathrm{H} /{ }^{14} \mathrm{C}\right)$ of ${ }^{3} \mathrm{H}$ and ${ }^{14} \mathrm{C}$ c.p.m. (.-.-.-- $)$.

and 2,000. Several differences were observed in the carbohydrate content and in the ninhydrin colour yield (after alkaline hydrolysis) between certain fractions of flocculent and non-flocculent cells.

Little information could be deduced from the pattern of transmittance at $280 \mathrm{~nm}$ because of the presence of polyphenolic and other unidentified contaminants whose strong absorption obscures that of the aromatic amino acids present in the peptides. Relative amino acid composition of all the gel filtration fractions was determined and the results are given in Table $\mathrm{V}$ and VI. There are certain similarities but also differences between parallel pairs of fractions derived from flocculent and nonflocculent yeast. Fraction IV originating from fraction 116-A-2 had a higher relative content of Asx, Gly, Tyr, Phe, and His and a lower con- tent of Ala and Lys than the corresponding fraction originating from 201-A-2. Low mol.wt. material resulting from $\beta$-mercaptoethanol treatment of strain 201 cells (fraction III from 201-B-2) had a higher content of Ser, Pro, Gly, $A l a$, and $V a l$ than the material from strain 116 cells (fraction III from 116-B-2). There were also differences observed in the two series of fractions resulting from the second trypsin treatment. Material derived from strain 201 cells had a higher content of Asx, Lys, and Arg than the corresponding material from strain 116 cells. Low mol.wt. material of strain 201 cells had a higher content of Pro, Gly, Ala, Tyr, His, Lys, and Arg than that obtained from strain 116 cells.

\subsection{Pronase digestion of radioactively labelled yeast cell residues}

In order to further investigate any structural differences that may be present in strain 116 and 201 yeast cell walls we labelled strain 116 cell residues (after two trypsin digestions and $\mathrm{NaCl}$-EDTA-SDS-treatment) with ${ }^{3} \mathrm{H}$-FDNB and strain 201 cell residues with ${ }^{14} \mathrm{C}$-FDNB and subjected them together to pronase digestion. The pronase digest was fractionated on a BioGel P-10 column. The elution pattern of this gel filtration is shown in Figure 3 and the summary of the results obtained on the isolated fractions in Table VII. It can be seen from the elution pattern that the pronase digest has been resolved essentially into three major groups of components. Constituents of high molecular weight approx. 10-20,000 (fractions 1, 2, and 3) had a high proportion of carbohydrates and relatively little ninhydrin colour, whereas components with the intermediate mol.wt., (fractions 5 and 6) and low molecular weights below 1,000 (fractions 7 and 8) had more ninhydrin colour and less carbohydrate. The fractions with high ninhydrin colour yield were also more heavily labelled with the radioactive FDNB-reagents. The value of ${ }^{3} \mathrm{H} /{ }^{14} \mathrm{C}$ ratio was not constant but varied from 4.1 to 6.7 for different fractions indicating differences in the labelling and suggesting that there were compositional differences in the constituents 


\section{Table VII}

Bio-Gel P-10 fractionation of pronase digest. Cell residues obtained after trypsin, $\beta$-mercaptoethanol and EDTA$\mathrm{NaCl}$-SDS treatment (see text) were labelled with ${ }^{3} \mathrm{H}$-FDNB or with ${ }^{14} \mathrm{C}$-FDNB. The ${ }^{3} \mathrm{H}$-labelled 116 cell residue $(4 \mathrm{~g})$ and the ${ }^{14} \mathrm{C}$-labelled 201 cell residue $(2 \mathrm{~g})$ were combined and digested with pronase yielding $\left.2.6^{\mathrm{a}}\right) \mathrm{g}$ of soluble material. This material was fractionated on Bio-Gel P-10 column as described in the text. The elution pattern is shown in Figure 3.

\begin{tabular}{l|c|c|c|c}
\hline \multirow{2}{*}{ Fraction } & \multirow{2}{*}{ Weight $(\mathrm{g})$} & \multicolumn{2}{|c|}{ c.p.m./fraction $\times 10^{-4}$} & \multirow{2}{*}{${ }^{3} \mathrm{H} /{ }^{14} \mathrm{C}$ ratio } \\
\cline { 3 - 4 } & 0.27 & ${ }^{3} \mathrm{H}$ & ${ }^{44} \mathrm{C}$ & 4.1 \\
\hline 1 & 0.41 & 28.4 & 6.9 & 5.9 \\
3 & 0.16 & 49.7 & 10.1 & 6.7 \\
4 & 0.09 & 60.8 & 7.0 & 6.0 \\
5 & 0.22 & 82.2 & 10.2 & 4.8 \\
6 & 0.59 & 131.1 & 26.3 & 5.0 \\
7 & 0.57 & 219.8 & 35.1 & 6.3 \\
8 & 0.08 & 282.0 & 41.9 & 6.7 \\
9 & 0.01 & 714.1 & 132.2 & 5.4 \\
\hline
\end{tabular}

a) Corrected for salt content.

derived from strain 116 and strain 201 cells. The total yield of radioactive counts after correction for counting efficiency losses (see section 3.7) was $3.9 \times 10^{7}$ c.p.m. for ${ }^{3} \mathrm{H}$ and $3.8 \times 10^{6}$ c.p.m. for ${ }^{14} \mathrm{C}$. This corresponds to $17.5 \mu \mathrm{Ci}$ of ${ }^{3} \mathrm{H}$ and $1.72 \mu \mathrm{Ci}$ of ${ }^{14} \mathrm{C}$ or $16 \mu \mathrm{g}$ and $15 \mu \mathrm{g}$ for the two FDNB reagents, respectively. Thus, only $7.0 \%$ and $3.4 \%$ of the initial quantity of the two reagents were covalently attached to the cell residues. This chemical modification would not be expected to have a significant effect on pronase digestion and, therefore, on the pattern of the eluted peptides from the column.

\section{DISCUSSION}

Previous studies concerning differences in the structure of the cell walls between flocculent and non-flocculent yeast were normally conducted on isolated cell wall material (14, 15). However, isolation of cell walls involves mechanical disruption of cells (20) which may lead not only to structural alterations in the wall but also to adsorption of intracellular material to the cell wall. Moreover, enzymatic digestion of such material would give rise to peptides originating not only from the outer surface of the wall but also from the inner surface. For these reasons, we decided to subject carefully washed intact flocculent (strain 201) and nonflocculent (strain 116) Saccharomyces carlsbergensis yeast cells to a sequential treatment with trypsin- $\beta$-mercaptoethanol-trypsin in the hope of solubilizing enough of the cell wall material to allow a chemical characterization of the released peptides.

The first trypsin treatment of the two types of cells released about $6 \%$ of material based on the dry weight of the starting material. Already in these fractions differences in amino acid composition were observed, while the carbohydrate contents of both fractions were similar. Fractionation of the digests on Sephadex G-100 revealed the presence of high mol.wt. (40,000 to 200,000 ) and low mol.wt. (less than 4,000) components and only little material between these extremes. The differences were found in the high mol.wt. components with the material from non-flocculent cells having a higher content of amino acids and less carbohydrate than the corresponding material from the flocculent cells.

When the trypsin treated cells were subjected to $\beta$-mercaptoethanol and to a second trypsin treatment, additional quantities of material were solubilized (see Table I). We have used $\beta$ - 
mercaptoethanol treatment for two reasons. The first was to liberate any tryptic fragments originating from the first digestion which might have been attached to the remaining part of the cell wall by disulfide linkages. Under the conditions employed we expected that these bridges would be reduced and the fragments released. The second reason was to reduce some of the more reactive disulfide bonds in the wall and solubilize additional wall fragments independent of the previous trypsin digestion. This possibility was suggested by the results obtained by DAVIES \& WAYMAN (6) who have treated Saccharomyces fragilis with $\beta$ mercaptoethanol and found that this treatment released a considerable amount of high and low mol.wt. material into solution. In addition, such a treatment would be expected to weaken the cell wall structure and a subsequent digestion of these $\beta$-mercaptoethanol-treated cells with trypsin might produce additional soluble fragments by hydrolyzing peptide bonds which were previously unaccessible to trypsin because of steric constraints in the cell wall structure. These expectations were actually born out by the experiments and we obtained two additional fractions of solubilized material from each of the two yeast types. As in the case of the first tryptic digest, the high molecular weight components of the fractions from strain 116 cells had a higher amino acid content and less carbohydrate than the material obtained from strain 201 cells. Similar results were also obtained with the low mol.wt. $(2,000$ to 4,000$)$ components although analytical data obtained on this material probably cannot be applied to consideration of the cell wall structure since it may be mixed with material originating from the cell interior as was shown in the study of Davies \& WAYMAN (6). However, the results obtained on the fractions having high mol.wt. material together with the results on carbohydrate content of the residual cells (see Table I) indicate that the flocculent yeast cell walls contain more carbohydrate and less protein than the non-flocculent cells. With regard to the protein content, it was of interest to find that many fractions of the flocculent cells had a considerably higher content of Pro, Lys, and Arg than the corresponding fractions of non-flocculent cells. Proline residues are known to have a special effect on the structure of proteins (1) being usually located at the corner of a bent polypeptide chain where two neighbouring more highly structured regions of the chain are joined together. Lys and Arg residues would tend to decrease the net negative charge of the cell surface and might in this manner promote cell aggregation.

One of the interesting aspects of this study was the detection of yeast and barley antigenic determinants in the high mol.wt. $(40,000$ to $200,000)$ material. All the fractions containing high mol.wt. material revealed the presence of yeast antigens. In contrast, only the tryptic digests of the two types of cells, but not the $\beta$ mercaptoethanol fractions, contained barleylike antigens. Moreover, non-flocculent cell fractions contained from 3 to 10 times more of barley antigens than the corresponding fractions from flocculent cells.

One of the methods used for comparing residual cell wall structures of the two types of cells was isotope double-labelling utilizing the same reagent with two different radioactive isotopes. We labelled the NaCl-EDTA-SDStreated strain 116 and 201 cell residues with ${ }^{3} \mathrm{H}$ FDNB and ${ }^{14} \mathrm{C}$-FDNB, respectively, and subjected these residues together to a single pronase digestion. Fractionation of this digest on Bio-Gel P-10 column revealed certain differences in the labelling pattern of the eluted peptides as reflected in variation of the ${ }^{3} \mathrm{H} /{ }^{14} \mathrm{C}$ ratio for different fractions. The high mol.wt. material and the material of mol.wt approximately 2,000 had ${ }^{3} \mathrm{H} /{ }^{14} \mathrm{C}$ of about 5 while the low mol.wt. material (less than 1,000 ) had a ratio of about 6.5 . This indicates that more of the low mol.wt. material was released from strain 116 cell residues than from strain 201 cell residues. These results are consistent with the previous results obtained with trypsin$\beta$-mercaptoethanol-trypsin treatment where it was also found that the fractions from strain 116 cells contained more protein and less carbohydrate than the corresponding fractions from strain 201 cells. 


\section{ACKNOWLEDGEMENT}

We are grateful to Drs. B. HJORTSHøJ and P. SIGSGAARD for providing samples of flocculent and non-flocculent cells of Saccharomyces carlsbergensis, to Mrs. LILLIAN ABILDGAard for excellent technical assistance and to other members of the laboratory for their kind help at various stages of this work. P. MARFEY thanks the Carlsberg Laboratory for financial support.

\section{REFERENCES}

1. Anfinsen, C. B. \& H. A. SCheraga: Experimental and theoretical aspects of protein folding. In: Advances in Protein Chemistry. C. B. Anfinsen, J. F. Edsall \& F. M. Richards eds., Academic Press, New York. Vol. 29, pp. 205-300 (1975)

2. Ashwell, G.: New colorimetric methods of sugar analysis. In: Methods in Enzymology. E. F. Neufeld \& V. Ginsburg eds., Academic Press, New York, Vol. 8, pp. 85-95 (1966)

3. Axelsen, N. H., J. KRøLL \& B. WeEkE: A Manual of quantitative immunoelectrophoresis. Methods and Applications. Universitetsforlaget, Oslo (1973)

4. Ballou, C. E.: Some aspects of the structure, immunochemistry and genetic control of yeast mannans. In: Advances in Enzymology. A. Meister ed., J. Wiley \& Sons, New York, Vol. 40, pp. 239-270(1974)

5. Bartlett, G. R.: Phosphorus assay in column chromatography. J. Biol. Chem. 234, 466-468 (1959)

6. Davies, R. \& F. J. WAYMan: The effect of thiols on Saccharomyces fragilis. J. Microbiol. Serol. 41, 33-58 (1975)

7. EDDY, A. A.: Flocculation characteristics of yeast. II. Sugars as dispersing agents. J. Inst. Brew. 61, 313-317 (1955)

8. Eddy, A. A. \& A. D. Rudin: Part of yeast surface apparently involved in flocculation. J. Inst. Brew. 64, 19-2! (1958)

9. HejgaArd, J. \& S. B. Sørensen: Characterization of a protein-rich beer fraction by twodimensional immunoelectrophoretic techniques. Compt. Rend. Trav. Lab. Carlsberg 40, 187-204 (1975)

10. Helm, E., B. Nøhr \& R. S. W. Thorne: The measurement of yeast flocculence and its significance in brewing. Wallerstein Lab. Commun. 16, 315-326 (1953)

11. Hirs, C. H. W.: Detection of peptides by chemical methods. In: Methods in Enzymology. C. H. W. Hirs ed., Academic Press, New York, Vol. 11, pp. 325-329 (1967)

12. ITO, U: The mechanism of flocculation of flocculent yeast during the wort fermentation. Mem. Coll. Sci. Univ. Kyoto, Ser. A 31 (2), 107.115, 117-125, 127-135 (1967)

13. JaYATISSA, P. M. \& A. H. Rose: Role of wall phosphomannan in flocculation of Saccharomyces cerevisiae. J. Gen. Microbiol. 96, 165-174 (1976)

14. Lyons, T. P. \& J. S. Hough: Flocculation of brewer's yeast. J. Inst. Brew. 76, 564-571 (1970)

15. LyONS, T. P.\& J. S. Hough: Further evidence for the crossbridging hypothesis for flocculation of brewer's yeast. J. Inst. Brew. 77, 300-305 (1971)

16. MiLL, P. J.: The nature of the interaction between flocculent cells in the flocculation of Saccharomyces cerevisiae. J. Gen. Microbiol. 35, 61-68 (1964)

17. Morris, E. O.: Aggregation of unicells: Yeast. In: The Fungi. G. C. Ainsworth \& A. S. Sussman eds., Academic Press, New York, Vol. 2, pp, $63-$ 82 (1966)

18. SMITH, D. \& H. O. Halvorson: The isolation of DNA from yeast. In: Methods in Enzymology. L. Grossman \& K. Moldave eds., Academic Press, New York, Vol. 12A, pp. 538-54l (1967)

19. Spackman, D. H., W. H. Stein \& S. Moore: Automatic recording apparatus for use in the chromatography of amino acids. Anal. Chem, 30, 1190-1206(1958)

20. Stewart, D. J. \& S. Widanapatirana; Fingerprint analysis of cell wall proteins from different yeast species after trypsinization. Microbios. 9, 167-172 (1974)

21. Stewart, G. G. \& T. E. Goring: Effect of some monovalent and divalent metal ions on the flocculation of brewers yeast strains. J. Inst. Brew. 82, 34l-342 (1976)

22. Taylor, N. W. \& W. I. Orton: Calcium in flocculence of Saccharomyces cerevisiae. J. Inst. Brew. 81, 53-57 (1975)

23. WYATT, G. R.: The purine and pyrimidine composition of deoxypentose nucleic acids. Biochem. J. $48,584-590$ (1951) 